\title{
Managerial Corporate Governance Communication
}

\author{
Silvio M. Brondoni*
}

\begin{abstract}
Corporate governance communication has steadily become more important as markets have globalised. On open markets, the specific report on economicfinancial disclosures supplements the communication system of companies, whose policies are founded strongly on integration, in order to tackle an economic context that is characterised by strong competitive dynamics and growing managerial complexity.

Globalisation tends to underline the importance of corporate governance communication designed to assert a corporate culture of competitive confrontation, therefore emphasising communication and information flows, decision-making autonomy and operating accountability.
\end{abstract}

Keywords: Corporate Governance Communication; Corporate Governance Models; Two-Tier System; One-Tier System; Global Markets; Financial Disclosure; Corporate Governance Communication and Information Tools; Corporate Culture

\section{Corporate Governance and Managerial Corporate Governance Communication}

In a dynamic, constantly changing scenario - which has expanded the corporate boundaries of research, finance, manufacturing and marketing - corporate governance communication takes on new market-oriented characteristics ${ }^{1}$, in a market-driven approach ${ }^{2}$, which emphasises its more specifically professional dimensions, and outlines a 'managerial corporate governance communication' that can put companies in a position to tackle the challenges of the global market ${ }^{3}$.

$\square$ 'Corporate governance is concerned with the nature of the interactions and relationships between the firm and its various stakeholders in the process of decision-making and in the term of control over firm resources. Corporate governance is to be understood

* Full Professor of Management, University of Milan-Bicocca (silvio.brondoni@ unimib.it)

Edited by: ISTEI - University of Milan-Bicocca

ISSN: 1593-0319

Brondoni Silvio M., Managerial Corporate Governance Communication, Symphonya. Emerging Issues in Management (symphonya.unimib.it), n. 1, 2006, pp. 8-23

http://dx.doi.org/10.4468/2006.1.02brondoni 
here, in general, as the interactions between internal actors, external actors and the board members in directing a corporation for value creation. For understanding corporate governance in a specific firm it is necessary to identify and understand the behaviour of the main actors, including the board members, external actors and internal actors, and the context in which governance takes place, 4

'Multinational corporations are at the forefront of the drive toward globalisation...The centrality of corporations' globalisation strategies becomes increasingly apparent...The importance of how corporations are governed - their ownership and control, the objectives they pursue, the rights they respect, the responsibilities they recognize, and how they distribute the value they create - has become a matter of the greatest significance, not simply for their directors and shareholders, but for the wider communities they serve, 5 .

In a modern managerial approach, corporate governance communication takes the shape of a specific relationship - based on continuity and responsibility - with the publics (internal, external and co-makers) to which the company must address its attention to develop a positive governance policy ${ }^{6}$.

'Globalisation affects the corporate governance in two ways. First, as trade barriers erode, the locally protected product marketplace disappears. A country's firms' performance is more easily measured against global standards. Poor performance shows up more quickly when a competitor takes away market share, or innovate quickly...Globalisation's second effect comes from capital markets' pressure on corporate governance...Firms expanding into global markets often prefer to use stock, rather than cash, as acquisition currency. If they want American investors to buy and hold that stock, they are pressed to adopt corporate governance measures that those investors feel comfortable with".

A 'managerial corporate governance communication' approach must first and foremost consider the behaviour necessary to meet the demand for corporate information and communication, and must therefore correlate with the guidelines of corporate governance actually adopted by the company. In particular, the corporate governance model, regulated by positive law, reflects the contrast between the so-called 'Two-Tier System' and the 'One-Tier System' (Figure 1) ${ }^{8}$.

The 'Two-Tier System' presupposes the separation of the managerial and control functions, producing two distinct organs: the Management Board, with governance functions, and the Supervisory Board, with control functions ${ }^{9}$.

The 'Two-Tier System' has recently been the subject of fierce debate, favoured by growing recourse to extraordinary financial operations related to mergers and acquisitions which, especially when they involve corporations of a significant size, make it necessary to reconcile the needs of the shareholders and management of the companies involved. 
Figure 1: Corporate Governance Models

\begin{tabular}{|l|l|}
\hline \multicolumn{2}{|l|}{ Corporate Governance models } \\
\hline 'TWO- TIER SYSTEM' & 'ONE- TIER SYSTEM' \\
$\begin{array}{l}\text { Separate Management and } \\
\text { Control Organs }\end{array}$ & Single Governance Organ \\
$\begin{array}{l}\text { Supervisory Board \& } \\
\text { Management Board }\end{array}$ & Board of Directors \\
\hline
\end{tabular}

Source: Silvio M. Brondoni, F. Gnecchi, 'Corporate Governance Communication' Seminar, University of Milan-Bicocca, 2006

The 'One-Tier System', on the other hand, presupposes that the corporate functions of management and control are exercised by a single organ, the Board of Directors. This organ therefore has all the powers necessary both to manage the company, and to control the activities undertaken ${ }^{10}$. In Italy, in particular, the small average size of companies seems to be the main reason for the prevalence of the 'One-Tier System'.

In order to meet the need for information and communication about corporate behaviour, and to correlate with the guidelines of corporate governance actually adopted by the company (i.e. the alternative 'One-Tier' or 'Two-Tier' models) a 'managerial corporate governance communication' approach, must come to terms with the chosen corporate model. Even in this case, we can identify two alternative guideline models, which do not in fact derive from precise legislation, but from the relevant specific national culture of the individual companies. In this context, we can identify the following models of corporate structure and prevailing orientation of communication and information flows:

- the Anglo-American model, which is characterised by highly fragmented ownership, i.e. a broad shareholder base, and a corporate culture that tends to be Market Oriented, which presupposes a particular and continuous focus on the outside world, for the very purpose of generating interest and consensus around the performance of the corporation and of attracting potential new parties willing to share the corporate risk;

- the European model, characterised by the predominant presence of companies with highly concentrated ownership, i.e. a small shareholder base; unlike the previous model, the European model is Insider Oriented, which entails a particular focus on the interests of those who already have a part of the capital stock.

The public company model needs to adopt clear, consistent criteria to regulate relations with management and the ownership, which may be fragmented among several providers of risk capital, configuring the so-called 'diffuse ownership'. What is more, in global companies, management also contributes to the competitive corporate vitality according to a 'diffuse' logic, with the result that the separation between ownership and management generates interpretative viewpoints (of analysis and evaluation) of the members of one group or the other that can diverge to a greater or lesser degree. External rating companies have sprung up to 
simplify the complex reality of global corporations, enjoying rapid success; their information/communication flows are often 'critically dialectic' with the company's corporate governance communication.

\begin{abstract}
$\square$ 'It is often argued that the majority of shareholders cannot be expected to discharge the traditional duties of stewardship that stem from ownership because they lack the necessary financial incentives. This argument against investor activism arises where there is a liquid market like in Britain and the United States so that typically ownership stakes are small in percentage terms...Shareholders activism or engagement derives from investors developing long-term face-to-face relationships with the companies in which they invest. Rather than their involvement being little more than that of anonymous speculators, they became the owners with an interest in the company progress... The need for this changer relationship has come out in recent years because of the increased dominance of financial institutions as shareholders... The growth in the size of pension funds and insurance companies means that increasingly, in many cases, institutional portfolios contain shares in a very large number of companies, if not every one listed on the market. At the same time relatively fewer shares are now held by individuals than in the past ${ }^{\text {, }}{ }^{11}$.
\end{abstract}

On the other hand, the European model, which favours an Insider Orientation, seems to limit corporate governance communication to the protection of the interests of risk capital providers, in other words, to favour the so-called shareholder view. In fact, global markets also force the so-called European model to adopt an 'open' form of management of $\mathrm{R} \& \mathrm{D}$, operations, finance, marketing and sales, with the result that the Shareholder View evolves into a more complex, ramified network approach. Where corporate governance communication is concerned, the European model thus tends to converge on the Anglo-American model and consequently the traditional dichotomy between the prevalence of the direction of inside/outside information flows tends to be surpassed by a new and more up-to-date dichotomy based on the competitive nature of the information flows, that reflects the Stakeholder View/Corporate View contradiction.

\title{
2. Corporate Governance. Communication and Information Tools
}

In the face of different corporate obligations and needs, corporate governance communication may be activated systematically, or occasionally. What is more, depending on the contents to be disseminated, it may regard compulsory documents (whose communication is imposed and regulated by laws and codes of practice), or discretional documents (made public by the company's choice, due to the importance of the subject). And finally, corporate governance communication may be disseminated using specific communication tools (as in the case of the publication of financial statement data and results), or suitable channels of information (for example, channelling corporate news and management data through specialist papers). For example, in the case of communication tools, the 
company activates specific forms of communication - addressing specific audience brackets - which allow it to exert complete control over the contents of the communication, and over the times and means of disseminating the message (which is obviously 'signed' by the company). However, the use of information channels also envisages the 'active' participation of the media, which 'sign' (and are therefore responsible) for the information contained in the corporate governance communication of a particular company ${ }^{12}$.

For example, where compulsory documents are concerned, legislation often specifies them in detail, even defining the minutest contents; one concrete example of this is the documents that accompany the annual summary of corporate results (statutory financial statements, board of auditors' report, external auditors' report, etc.). Other documents have recently been made necessary by specific legislation, for example, the Ethics Code regarding administrative accountability ${ }^{13}$. The dissemination of discretional documents is a result of the corporate culture of openness to the markets (although it can generally be noted that this decreases as the integration of networking made necessary by the global market increases) and it is linked in particular to the specific sensitivity that each company reveals to corporate communication ${ }^{14}$. For example, with an 'environmental report' or a 'social report', but also an 'intangibles report' or 'gender budgeting'.

Figure 2 below indicates the main tools of communication and information that are a part of managerial corporate governance.

Figure 2: Corporate Governance - Communication and Information Tools

\section{Corporate Governance \\ Primary Communication/Information Tools}

- $\quad$ Corporate Governance Report

Statutory Financial Statements (yearly, interim, consolidated)

Board of Auditors' Report

External Auditors' Report

Ethics Code

Intangibles Report

Environmental Report

Social Report

Gender Budget

Information about relations between parent company and subsidiary companies (e.g. joint ventures, acquisitions and disposals of company branches and significant equity investments, etc.)

Information about meetings with market operators

Interviews and declarations to mass media

Information about Corporate Responsibility

Information about Corporate Social Responsibility

Information about Social / Educational / Research Partnerships

Source: Silvio M. Brondoni, F. Gnecchi, 'Corporate Governance Communication' Seminar, University of Milan-Bicocca, 2006

The 'Corporate Governance Report' is therefore a brief document that presents the structures and procedures of corporate governance, whose preparation and dissemination - voluntary, but often recommended by company auditing organisms 
- outlines the company's orientation to openness and transparency with its primary and secondary interlocutors ${ }^{15}$.

Figure 3: Key Issues in the 'Corporate Governance Report'

- $\quad$ Board Structure\& Director Qualifications

(Composition of the Board; Selection of Board Members; Directors Qualification Standards; Board Leadership; Committees of the Board; Term, Retirement, Resignation)

- Board Responsibilities, Compensation, Orientation \& Continuing Education

(Approval of Major Strategies and Financial Objectives; Executive \& Director Compensation; Board Interaction with Outside Constituencies; Director Orientation \& Continuing Education; Conflict of Interest)

- $\quad$ Board Operations: Access to Management \& Advisors

(Director Interaction with Management; Access to Independent Advisors)

Source: Silvio M. Brondoni, F. Gnecchi, 'Corporate Governance Communication' Seminar, University of Milan-Bicocca, 2006

\section{Corporate Governance: Information and Communication in the Stakeholders View and the Corporate View}

The economic wellbeing of the last thirty years, the improved literacy and the spread of digital information and communications technologies have helped to make consumers, suppliers and investors more expert and careful in their purchasing and investment behaviour ${ }^{16}$. Once easily manipulated, consumers, suppliers and investors evolve in markets where relations between supply and demand (final and intermediate) are based on networking relations, competition is very strong and is developed on open markets, and finally a wide range of sources of information is available and accessible at ever-lower costs, modifying the very nature of relations between the global enterprise and its internal and external interfaces.

$\square$ 'The recent scandals in corporations have made many
commentators reflect and react for creating sustainable value for
shareowners, customers, employees and communities...A governance
revolution seems to be taking place, and while many official reforms
have already been passed following Enron's meltdown, board are going
even further, instituting sweeping changes in their composition,
structure, and practices on a scale not seen since skyrocketing executive
pay gave birth to the modern governance movement in the 1980s' 17 .

Global managerial economics thus increasingly reveal the contrasting vision that is inherent in the so-called corporate view (i.e. the corporate and unitary perspective of the corporation), distinguishing it from the stakeholder view (i.e. the multiform and very differentiated perspective expressed by the various stakeholders) where corporate governance communication is concerned (Figure 2). In this context, for example, the increase in consumers' critical capability in open markets contributes directly to the improvement of the market on the final demand side (which translates into greater opportunities for choice at a lower cost). At the same time it determines new needs for 
transparency and accountability on the part of supply and the different levels of intermediate demand (retailers, wholesalers, purchasing groups, communities, etc.). In fact, taken as a whole, a lack of choice, access to information, pressure on prices, striving for product safety, and disloyalty in commercial transactions modify relations between consumers, trade and industry, to the benefit of a new sense of responsibility on the part of businesses. Similarly, in the context of relations between a certain business, the media and the public, global markets tend to develop new forms of consumer consciousness which generates pressure groups that force growing attention on the limitations of natural resources, the uncontrollable growth of waste and the social costs of the various types of consumption. These choices can modify the determinants of consumption of specific goods (for example furs of protected species, beauty products whose experimentation exploits vivisection, etc.), proposing the recognition of the social costs of use of the environment.

Figure 4: Stakeholder View and Corporate View

\begin{tabular}{|c|}
\hline Stakeholder View vs. Corporate View \\
Equity / Asymmetrical information \\
Correctness / Specificity \\
Comprehensiveness / Partiality \\
Timeliness / 'Timing News' Control \\
Transparency / Opacity
\end{tabular}

Source: Silvio M. Brondoni, F. Gnecchi, 'Corporate Governance Communication' Seminar, University of Milan-Bicocca, 2006

More generally, as Figure 4 shows, in the economics of global corporations' market relations, the perspective of the stakeholders' 'public' interests tends to instil value in a corporate governance communication policy based on standards of equity in information, i.e. information disclosed symmetrically to the various internal, co-maker and external interlocutors ${ }^{18}$. On the other hand, the corporate perspective tends to reward a managerial function that presupposes asymmetrical information flows, which envisage that the openness of the corporate system is graduated to the different publics present on the various markets. This openness is connected directly to the interest shown by individual groups of interlocutors.

What is more, the stakeholder view presupposes 'correct' corporate governance communications (i.e. designed to present a given corporate event with an uncritical sentiment, without 'forcing' its interpretation in line with precise, and often not immediately comprehensible, corporate interests) and 'comprehensive' (i.e. interpreting company events examined from various viewpoints, in order to prevent possible speculation and controversy). On the other hand, the corporate view tends to disclose 'specific' information (with an 'interpretation' designed to pursue definite and contingent corporate interests and disseminated by the most suitable channels) and 'partial (with a deliberately limited 'view' of facts and events, to emphasise the positive aspects for the organisation).

\section{'Industry and a competitive environment are among the factors that, in general, are presumed to influence corporate governance...}




\begin{abstract}
Governance systems may vary significantly between knowledgeintensive firms and capital-intensive firms. Some of these differences may also relate to variations in property rights... In stakeholdersensitive industries there may be particular emphasis on transparency and accountability. Boards in such industries will, more than boards in other industries, be related to various stakeholder concerns such as corporate social responsibility. This is the case, for example, in highly polluting industries, the energy sector the health care sector, etc' ${ }^{19}$.
\end{abstract}

And finally, the stakeholder view presupposes corporate governance communications that are 'timely' and 'transparent' (characteristics with an obvious significance, which do not require specific explanation, referred directly to basic sentiments, which are elementary and easily shared $)^{20}$. Therefore, from a corporate viewpoint, corporate governance communication often tends to be distinguished by 'Timing News Control' (i.e. disclosure of information to the various publics and stakeholders that is partial, strongly controlled in its contents, timing and method of dissemination) and 'information opacity' (i.e. a generalised tendency to 'remain one step behind' compared to the information expectations expressed by stakeholders) ${ }^{21}$.

\title{
4. Corporate Governance, Communication and Global Corporations
}

At the end of the Nineties and the early years of the new Millennium, there was a rapid acceleration in the globalisation of the world economy ${ }^{22}$.

Competition has become global and for numerous sectors the target market is no longer a State or a continent, but vast groupings of industrialised countries. This phenomenon, which is particularly evident in Europe because of the size of domestic markets, has made traditional multinational organisations (multidomestic corporations) obsolete, and they have been replaced by forms of transnational organisation (network organisation), which are able to face up to the economic interdependence of the target markets (global markets). Domestic markets are no longer separate spaces but must be managed as vast aggregates of target markets, because what takes place in one market influences all the others ${ }^{23}$.

Corporate governance communication has steadily become more important as markets have globalised. On open markets, the specific report on economic-financial disclosures supplements the communication system of companies, whose policies are founded strongly on integration ${ }^{24}$, in order to tackle an economic context that is characterised by strong competitive dynamics and growing managerial complexity.

In global markets, corporate governance communication interfaces on one side with the new role of the Nation-State ${ }^{25}$, and on the other with the structure of the 'network organisation' of the global corporation.

$\square$ In the contemporary story of transnationalisation of antitrust... the path currently threaded privileges the development of normative institutions or rules of the game-common beliefs and cultural valuesover the setting-up of structures, organizations and binding regulation. 
It appears to favour mechanisms of self-regulation, socialization and self-responsabilisation over logics of coercion and external constraints... The concept of hegemony appears more directly useful and applicable in this context. The ways in which the games of negotiation and collective decision-making will combine and interact with hegemonic processes in the coming years still remains to be seen $^{26}$.

First of all, where the role of the State is concerned, the globalisation of the economy reveals new problems to manage specific national forces and resources. As open markets take hold, national governments tend to lose some of their prerogatives, to the extent that their transnational authority weakens ${ }^{27}$. A market economy demands a strong State that sets and enforces the rules of the competitive game, but globalisation also undermines the role of national governments. As a result, global capitalism favours the development of powerful supranational institutions (like the European Commission on the issue of the protection of privacy, the Directorate for competition, the O.E.C.D. on the issue of corruption, the World Bank, the International Monetary Fund, the World Trade Organisation), which, also drawing on the knowledge network structures, can issue consistent directives that orient the decisional sphere of national governments, particularly with regard to environmental, food and healthcare problems ${ }^{28}$.

$\square$ 'Today there is no lack of data informing the general economic debate...However, the reports and releases coming from central bank have a special status... The knowledge production of central banks is considered particularly apt, relevant and consequential. Central bankers constitute a global knowledge community... This autonomous and self-governing knowledge community can be depicted as a Transnational governance network ${ }^{29}$.

In addition to the new role of the Nation-States, in global markets corporate governance communication must also come to terms with the new problems of the development of supranational demand segments, or groups of investors, customers and suppliers present in each country with similar behaviour or similar expectations ${ }^{30}$.

Globalisation therefore does not simplify corporate governance by homogenising (or standardising) the managerial conduits of corporations in the various countries, but highlights the fact that in each country there are groups of stakeholders with the same needs, that can therefore be approached with the same corporate policies (i.e. with identical brands, common funding plans, etc.) ${ }^{31}$.

The new context of global competition has drastically modified the role of strategic alliances, imposing a collaborative network logic between groups of companies with similar profiles and dimensions ${ }^{32}$. In fact, the multinationals from developing economies are structured to compete at a global level (typically in networks and constellations of companies), while the larger multinationals of industrialised economies promote numerous forms of competitive cooperation, through strategic alliances both equity and non-equity. 'Strategic competitive collaboration alliances' highlight the common competitive network structure 
adopted today by companies operating on global, over-supplied markets, where the company performance of individual units (local) and overall at corporate level (global), imposes a new and fundamental concept of corporate accountability, which sees sustainable growth as a corporate development benchmark.

The globalisation of the markets determines new competition paradigms: companies must be able to compete according to 'market-space competition' logics, proposing competitive boundaries in which the definition of the rules that companies must conform to cannot be oriented by technical characteristics, even when these are important, such as the choice of the two-tier model instead of the one-tier model. In fact, on open markets, competition space is redefined by 'market-space management' logics and as a result it is difficult to define in sectors of activity, but can more appropriately be linked to systems of intangible resources that help to qualify companies' competitive profiles ${ }^{33}$.

And finally, the challenges of globalisation determine the orientation of the company to the market focusing on the concept of customer value management, i.e. a continuative approach designed to offer goods/services with a higher value than those of the competition to selected aggregates of demand (market-driven management). In fact, we tend to overcome the customer orientation which favours the expectations of the customer/consumer and shows itself to be inadequate on highly competitive markets, primarily developing the competitive dimension of the demand vacuum. A competitive approach to the market (market-driven management) is therefore designed to guarantee an efficient intersection between demand (intermediate and final) and supply, developing products (new and improved, and in any case able to satisfy 'demand bubbles' better than competitors) and organising physical trade and communication flows (push/pull communication) between the company and its clientele. This approach presupposes a market-driven managerial mind-set which requires: a corporate structure organised by market rather than by product or plant; a corporate culture oriented to results and motivated by variable demand and instability in the context of competition; the preparation of new metrics of intangible and tangible factors, to estimate the corporate performance in external and changing contexts ${ }^{34}$.

Market-space competition conditions define sophisticated competition boundaries with a global matrix, in which space and time combine to form and dynamically modify the relevant competitive context, thus making the evaluation of any conditions of market predominance particularly difficult to assess using traditional and consolidated performance and position indices ${ }^{35}$.

In the last two decades, the globalisation of corporate organisation, and encroaching over-supply, has induced numerous large corporations to develop plans to extend their activities, according to a global corporate viewpoint, which tends to reorganise distinctive competitive capabilities in search of vaster economies of scale, activating corporate aggregations that are difficult from a legalcorporate point of view, but above all in terms of the integration of different national corporate cultures.

As a result, globalisation tends to underline the importance of corporate governance communication designed to assert a corporate culture of competitive confrontation, therefore emphasising communication and information flows, decision-making autonomy and operating accountability. 
The transformation from a local company (and then from a multidomestic company) to a global network organisation, i.e. a company with several competitive spaces, questions certain consolidated concepts (including the disquisition of the 'one-tier'/'two-tier' system) because space becomes the critical element, which demands a commitment to 'hold together' management that is often 'dispersed' in 60/80 countries and often also fragmented ownership.

Corporate governance communication of global 'network organisations' therefore interfaces with employees, co-makers and partners - in a dimension of transparent integration - emphasising the 'corporate ethics' of the new values of citizenship of the global corporation.

\section{Bibliography}

Aguilera Ruth V., Jackson Gregory, The Cross-National Diversity of Corporate Governance: Dimensions and Determinants, Academy of Management Review, n. 28, 2003, pp. 447-465. http://dx.doi.org/10.5465/AMR.2003.10196772

Annan Kofi, The Global Compact. Corporate Leadership in the World Economy, Symphonya. Emerging Issues in Management (symphonya.unimib.it), n. 2, 2002. http://dx.doi.org/10.4468/2002.2.02annan

Bisio Luca, Global Market and Public Governance in Europe, Symphonya. Emerging Issues in Management (symphonya.unimib.it), n. 1, 2004. http://dx.doi.org/10.4468/2004.1.07bisio

Bisio Luca, Global Companies and Global Regulation, Symphonya. Emerging Issues in Management (symphonya.unimib.it), n. 1, 2005. http://dx.doi.org/10.4468/2005.1.07bisio

Bosetti Luisa, La gestione del consenso e le relazioni di governo, Daniela M. Salvioni (ed.), Corporate Governance, controllo di gestione e risorse immateriali, Franco Angeli, Milan, 2004.

Brondoni Silvio M., Comunicazione integrata e 'nuove sfide' competitive, R. Filippini, G. Pagliarani, G. Petroni (eds.), Progettare e gestire l'impresa innovativa, Etas Libri, Milan, 1992.

Brondoni Silvio M., La comunicazione integrata d'impresa, Gianpiero Lugli (ed.), Comunicazione e pubblicità. Analisi economica e dinamiche competitive, Egea, Milan, 1993.

Brondoni Silvio M., Comunicazione, risorse invisibili e strategia competitiva d'impresa, Sinergie, $\mathrm{n}$. 43-44, 1997.

Brondoni Silvio M., Ouverture de 'Market-Space Management', Symphonya. Emerging Issues in Management (symphonya.unimib.it), n. 1, 2002.

http://dx.doi.org/10.4468/2002.1.010uverture

Brondoni Silvio M., Global Markets and Market-Space Competition, Symphonya. Emerging Issues in Management (symphonya.unimib.it), n. 1, 2002. http://dx.doi.org/10.4468/2002.1.03brondoni

Brondoni Silvio M., Ouverture de 'Corporate Culture and Market Complexity', Symphonya. Emerging Issues in Management (symphonya.unimib.it), n. 2, 2002. http://dx.doi.org/10.4468/2002.2.01ouverture

Brondoni Silvio M., Network Culture, Performance \& Corporate Responsibility, Symphonya.Emerging Issues in Management (symphonya.unimib.it), n. 1, 2003. http://dx.doi.org/10.4468/2003.1.02brondoni 
Brondoni Silvio M., Risorse immateriali e concorrenza d'impresa, Silvio M. Brondoni (ed.), Il sistema delle risorse immateriali d'impresa: cultura d'impresa, sistema informativo e patrimonio di marca, Giappichelli, Turin, 2004.

Brondoni Silvio M., Network e cultura della concorrenza, Silvio M. Brondoni (ed.), Cultura di network, performance e dinamiche competitive, Giappichelli, Turin, 2006.

Child John, Rodriguez Suzana B., The International Crisis of Confidence in Corporations, Journal of Management and Governance, n. 7, 2003, p. 223. http://dx.doi.org/10.1023/A:1025062422500

Clark Thomas, de la Rama Marie, Corporate Governance and Globalisation, Sage, London, 2006. p. 31 .

de Woot Philippe, The Challenges of Economic Globalisation: Business, Competition and Society, Symphonya. Emerging Issues in Management (symphonya.unimib.it), n. 2, 2002.

http://dx.doi.org/10.4468/2002.2.03dewoot

Djelic Marie-Laure, Kleiner Thibaut, The International Competition Network: Moving towards Transnational Governance, Marie-Laure Djelic, Kerstin Sahlin-Andersson (eds.), Transnational Governance. Institutional Dynamics of Regulation, Cambridge University Press, Cambridge, 2006, p. 306 http://dx.doi.org/10.1017/CBO9780511488665.015

Fiori Giovanni, Tiscini Riccardo, Di Donato Francesca, Corporate Governance, evoluzione normativa ed informazione esterna d'impresa, Daniela M. Salvioni (ed.), Corporate Governance e sistemi di controllo della gestione aziendale, Franco Angeli, Milan, 2004.

Gandini Giuseppina, Il sistema delle risorse immateriali, Daniela M. Salvioni (ed.), Corporate Governance, controllo di gestione e risorse immateriali, Franco Angeli, Milan, 2004.

Gandini Giuseppina, Corporate Governance, controllo di gestione e risorse immateriali d'impresa, Daniela M. Salvioni (ed.), Corporate Governance e sistemi di controllo della gestione aziendale, Franco Angeli, Milan, 2004.

Gatti Mauro, Cultura d'impresa, risorse immateriali e competitività, Silvio M. Brondoni (ed.), Il sistema delle risorse immateriali d'impresa: cultura d'impresa, sistema informativo e patrimonio di marca, Giappichelli, Turin, 2004.

Gnecchi Flavio, Corporate Governance nell'impresa a rete, Silvio M. Brondoni (ed.), Cultura di network, performance e dinamiche competitive, Giappichelli Turin, 2006.

Huse Morten, Neubaum D.O., Gabrielsson Jonas, Corporate Innovation and Competitive Environment, International Entrepreneurship and Management Journal, n. 1, 2005, p. 313-333. http://dx.doi.org/10.1007/s11365-005-2596-2

Lambin Jean-Jacques, Brondoni Silvio M., Ouverture de 'Market-Driven Management', Symphonya. Emerging Issues in Management (symphonya.unimib.it), n. 2, 2000-2001. http://dx.doi.org/10.4468/2001.2.01ouverture

Lambin Jean-Jacques, Strategic Marketing Revisited after September 11 Symphonya. Emerging Issues in Management (symphonya.unimib.it), n. 1, 2002. http://dx.doi.org/10.4468/2002.1.02lambin

Lambin Jean-Jacques, Economia di mercato vs. economia sociale di mercato. Verso un modello economico europeo?, Silvio M. Brondoni (ed.), Cultura di network performance e dinamiche competitive, Giappichelli, Turin, 2006.

Leech Dennis, Incentives to Corporate Governance Activism, Michael Waterson (ed.), Competition, Monopoly and Corporate Governance, Edward Elgar, Cheltenham, 2003, pp. 206-207.

Marcussen Martin, The Transnational Governance Network of Central Bankers, Marie-Laure Djelic, Kerstin Sahlin-Andersson (eds.), Transnational Governance. Institutional Dynamics of Regulation, Cambridge University Press, Cambridge, 2006, p. 180. 
Neil Gordon Jeffrey, Roe Mark J., Convergence and Persistence in Corporate Governance, Cambridge University Press, Cambridge, 2004, p. 42.

Salvioni Daniela M., Il bilancio d'esercizio nella comunicazione integrata d'impresa, Giappichelli, Turin, 1992.

Salvioni Daniela M., Comunicazione, cultura e governo economico d'impresa, Silvio M. Brondoni (ed.), La comunicazione d'impresa, Sinergie, May-December 1997, p. 69.

Salvioni Daniela M., Transparency Culture and Financial Communication, Symphonya. Emerging Issues in Management (symphonya.unimib.it), n. 2, 2002.

http://dx.doi.org/10.4468/2002.2.04salvioni

Salvioni Daniela M., Il sistema di governo aziendale, Daniela M. Salvioni (ed.), Corporate Governance e sistemi di controllo della gestione aziendale, Franco Angeli, Milan, 2004.

Salvioni Daniela M., Efficacia aziendale, processi di governo e risorse immateriali, Daniela M. Salvioni (ed.), Corporate Governance, controllo di gestione e risorse immateriali, Franco Angeli, Milan, 2004.

Webster Jr. Frederick E., Market-Driven Management, John Wiley \& Sons, Hoboken, 2002.

\section{Notes}

1 'Globalisation forces us to instil value into a corporate culture that strives for competitive confrontation and therefore to develop communication and information flows, manufacturing decentralisation, decision-making autonomy and operating accountability ...In conditions of marketspace competition, businesses operate with ramified, disseminated and strongly interconnected structures. In these complex markets, internal relations between employees must develop in harmony with vaster systems of continuous connections maintained with co-makers and external interlocutors, and therefore the organisational culture must open up to a more competitive view of corporate culture.' See Silvio M. Brondoni, Network e cultura della concorrenza, in Silvio M. Brondoni (ed.), Cultura di network performance e dinamiche competitive, Giappichelli, Turin, 2006, p. 4.

${ }^{2}$ Cf. Jean-Jacques Lambin, Silvio M. Brondoni, Ouverture de 'Market-Driven Management', Symphonya. Emerging Issues in Management (symphonya.unimib.it), n. 1, 2000-2001.

${ }^{3}$ Cf. Silvio M. Brondoni, Comunicazione integrata d'impresa e 'nuove sfide' competitive, in R. Filippini, G. Pagliarani, G. Petroni (eds.), Progettare e gestire l'impresa innovativa. I nuovi percorsi per affrontare la complessità degli anni Novanta, Etaslibri, Milan, 1992.

${ }^{4}$ See John Child, Suzana B. Rodriguez, The International Crisis in Confidence in Corporations, Journal of Management and Governance, 2003, n. 7, p. 213.

${ }^{5}$ See Thomas Clark, Marie de la Rama, Corporate Governance and Globalisation, Sage, London, 2006, p. 31.

6 'The integrated approach to corporate communication - designed to conceive in a single vision the various initiatives to support the acquisition of the necessary intra-organisational and intercompany consensus - not infrequently represents the assumption of managerial effectiveness conveniently associated to processes of economic governance.' See Daniela M. Salvioni, Comunicazione, cultura e governo economico d'impresa, in Silvio M. Brondoni (ed.), La comunicazione d'impresa, Sinergie, May-December 1997, p. 69.

${ }^{7}$ See Jeffrey Neil Gordon, Mark J. Roe, Convergence and Persistence in Corporate Governance, Cambridge University Press, Cambridge, 2004, p. 42.

${ }^{8}$ Cf. Daniela M. Salvioni, Il sistema di governo aziendale, in Daniela M. Salvioni (ed.), Corporate Governance e sistemi di controllo della gestione aziendale, Franco Angeli, Milan, 2004. 
9 'In the typical Continental European two-board system there is one supervisory board and one executive board. The supervisory board consist of non-executives, often representing shareholders and various other shareholder groups. The executive board has the day-to-day tasks delegated to it. The executive board consists of the TMT, and the CEO is usually the chairperson of the executive board. It is the supervisory board that is called the 'board'. In the Scandinavian model there is oneboard system, but the board members are generally non-executives elected by the shareholders. It is compulsory to delegate the day-to-day running to a CEO, and is therefore a two-tier system. The CEO can be replaced by an executive board, but in practice this hardly ever happens'. See Ruth V. Aguilera, Gregory Jackson, The Cross-National Diversity of Corporate Governance: Dimensions and Determinants, Academy of Management Review, n. 28, 2003, pp. 447-465, passim.

10 'In the Anglo-American model there is one board, which also has direct responsibility for the day-to-day running of the firm. The board typically consists of the CEO, members of the top management team and a few non-executives. The non-executives are traditionally added to provide external resources and manage resource dependencies'. See Ruth V. Aguilera, Gregory Jackson, The Cross-National Diversity of Corporate Governance: Dimensions and Determinants, Academy of Management Review, n. 28, 2003, pp. 447-465, passim.

11 See Dennis Leech, Incentives to Corporate Governance Activism, in Michael Waterson, Competition, Monopoly and Corporate Governance, Edward Elgar, Cheltenham, 2003, pp. 206-207.

${ }^{12}$ Cf. Silvio M. Brondoni, Comunicazione, risorse invisibili e strategia competitiva d'impresa, Sinergie, n. 43-44, May-December 1997.

${ }^{13}$ Cf. Giovanni Fiori, Riccardo Tiscini, Francesca Di Donato, Corporate Governance, evoluzione normativa ed informazione esterna d'impresa, in Daniela M. Salvioni (ed.), Corporate Governance e sistemi di controllo della gestione aziendale, Franco Angeli, Milan, 2004.

${ }^{14}$ Cf. Flavio Gnecchi, Corporate Governance nell'impresa a rete, in Silvio M. Brondoni (ed.), Cultura di network performance e dinamiche competitive, Giappichelli Turin, 2006.

${ }^{15}$ Cf. Luisa Bosetti, La gestione del consenso e le relazioni di governo, in Daniela M. Salvioni (ed.), Corporate Governance, controllo di gestione e risorse immateriali, Franco Angeli, Milan, 2004

16 ،...in the general company system, it is now possible to outline a specific communication subsystem, designed to grasp existing opportunities and constraints... In other words, we have acquired understanding of the forms of communication implicit in the development of the general economic combination... In the same way, we have understood the increased potential to transmit explicit messages, i.e. structured specifically and transmitted to positively influence company dynamics.' See Daniela M. Salvioni, Il bilancio d'esercizio nella comunicazione integrata d'impresa, Giappichelli, Turin 1992, pp. 26-27.

${ }^{17}$ See Business Week, 7 October 2002, p. 58.

${ }^{18}$ Regarding the distinctive characteristics of external, internal and co-maker publics, we refer you to: Silvio M. Brondoni, La comunicazione integrata d'impresa, in Gianpiero Lugli (ed.), Comunicazione e pubblicità. Analisi economica e dinamiche competitive, Egea, Milan, 1993.

19 See Morten Huse, D.O. Neubaum, Jonas Gabrielsson, Corporate Innovation and Competitive Environment, International Entrepreneurship and Management Journal, n. 1, 2005, p, 313 and following.

20 'Industry and a competitive environment are among the factors that, in general, are presumed to influence corporate governance... Governance systems may vary significantly between knowledgeintensive firms and capital-intensive firms. In stakeholders-sensitive industries there may be particular emphasis on transparency and accountability. Boards in such industries will, more than boards in other industries, be related to various stakeholders concerns such as corporate social responsibility. This is the case, for example, in highly polluting industries, the energy sector, the health care sector, etc.'. See Morten Huse, D.O. Neubaum, Jonas Gabrielsson, Corporate innovation and Competitive Environment, International Entrepreneurship and Management Journal, 1, 2005, pp. 313-333. 
21 'The values of transparency identify an essential requirement for the continuous adjustment of the convergence between the management and content of information... The recent economic disasters, and the mendacity of communications... should induce companies to understand the importance of transparency to improve intercompany relations... The culture of transparency also represents an ethical principle of orientation for all those who, for various reasons (for example, auditors, governance organisms, etc.) are required to legitimise the content of economic communication'. See Daniela M. Salvioni, Transparency Culture and Financial Communication, Symphonya. Emerging Issues in Management (symphonya.unimib.it), n. 2, 2002.

22 'There are numerous impregnated companies in the Global Pact and they represent different sectors and geographical areas. However, they all share two characteristics: they are leading companies and they aspire to manage responsible global growth that takes into consideration the interests and concerns of a broad spectrum of stakeholders - which include employees, investors, customers, protection groups, commercial partners and local communities.' See Kofi Annan, The Global Compact. Corporate Leadership in the World Economy, Symphonya. Emerging Issues in Management (symphonya.unimib.it), n. 2, 2002, p 13.

${ }^{23}$ Cf. Silvio M. Brondoni, Network e cultura della concorrenza, in Silvio M. Brondoni (ed.), Cultura di network performance e dinamiche competitive, Giappichelli Turin, 2006.

${ }^{24}$ Cf. Silvio M. Brondoni, Ouverture de 'Market-Space Management', Symphonya. Emerging Issues in Management (symphonya.unimib.it), n. 1, 2002.

25 Cr. Luca Bisio, Global Companies and Global Regulation, Symphonya. Emerging Issues in Management (symphonya.unimib.it), n. 1, 2005; Luca Bisio, Global Market and Public Governance in Europe, Symphonya. Emerging Issues in Management (symphonya.unimib.it), n. 1, 2004.

${ }^{26}$ See Marie-Laure Djelic, Thibaut Kleiner, The International Competition Network: Moving towards Transnational Governance, in Marie-Laure Djelic, Kerstin Sahlin-Andersson (eds.), Transnational Governance. Institutional Dynamics of Regulation, Cambridge University Press, Cambridge 2006, p. 306.

${ }^{27}$ Cf. Philippe de Woot, The Challenge of Economic Globalisation: Business, Competition and Society, Symphonya. Emerging Issues in Management (symphonya.unimib.it), n. 2, 2002.

${ }^{28}$ Cf. Jean-Jacques Lambin, Economia di mercato vs. economia sociale di mercato. Verso un modello economico europeo?, in Silvio M. Brondoni (ed.), Cultura di network performance $e$ dinamiche competitive, Giappichelli Turin, 2006.

${ }^{29}$ See Martin Marcussen, The Transnational Governance Network of Central Bankers, in MarieLaure Djelic, Kerstin Sahlin-Andersson (eds.), Transnational Governance. Institutional Dynamics of Regulation, Cambridge University Press, Cambridge 2006, p. 180.

${ }^{30}$ Cf. Jean-Jacques Lambin, Strategic Marketing Revisited After September 11, Symphonya. Emerging Issues in Management (symphonya.unimib.it), n. 1, 2002.

${ }^{31}$ Cf. Silvio M. Brondoni, Global Markets and Market-Space Competition, Symphonya. Emerging Issues in Management (symphonya.unimib.it), n. 1, 2002.

${ }^{32}$ Cf. Mauro Gatti, Cultura d'impresa, risorse immateriali e competitività, in Silvio M. Brondoni (ed.), Il sistema delle risorse immateriali d'impresa: cultura d'impresa, sistema informativo e patrimonio di marca, Giappichelli, Turin, 2004.

${ }^{33}$ Cf. Silvio M. Brondoni, Risorse immateriali e concorrenza d'impresa, in Silvio M. Brondoni (ed.), Il sistema delle risorse immateriali d'impresa: cultura d'impresa, sistema informativo $e$ patrimonio di marca, Giappichelli, Turin, 2004; Giuseppina Gandini, Il sistema delle risorse immateriali, in Daniela M. Salvioni (ed.), Corporate Governance, controllo di gestione e risorse immateriali, Franco Angeli, Milan, 2004; Giuseppina Gandini, Corporate Governance, controllo di gestione e risorse immateriali d'impresa, in Daniela M. Salvioni (ed.), Corporate Governance e sistemi di controllo della gestione aziendale, Franco Angeli, Milan, 2004; Daniela M. Salvioni, 
Efficacia aziendale, processi di governo e risorse immateriali, in Daniela M. Salvioni (ed.), Corporate Governance, controllo di gestione e risorse immateriali, Franco Angeli, Milan, 2004.

34 'To be market-driven is more than simply customer-driven and it requires more than customer orientation. While customer orientation remains as the prime idea within the marketing concept, to be market-driven also means being aware of competitors' product offering and capabilities as they are viewed by customers. It means understanding the intersection of customer needs and company capabilities in the context of competitors' product offering as these three things come together in the customer's definition of value. To be market-driven requires that all decision making is informed by customer information, competitive intelligence, and a clear concept of the company's value proposition'. See Frederick E. Jr. Webster., Market-Driven Management, John Wiley \& Sons, Hoboken, 2002.

${ }^{35}$ Cf. Silvio M. Brondoni, Ouverture de 'Corporate Culture and Market Complexity', Symphonya. Emerging Issues in Management (symphonya.unimib.it), n. 2, 2002; Silvio M. Brondoni, Network Culture, Performance and Corporate Responsibility, Symphonya. Emerging Issues in Management (symphonya.unimib.it), n. 1, 2003. 